\title{
journal of baltic studies
}

The Journal of Baltic Studies, now in the 28 th year of publication, is a scholarly journal presenting articles and book reviews in English, German and French, bibliographical notes, reports on research by scholars working in the field of Baltic Studies, as well as information on courses and programs at institutions of higher learning. The Journal is published quarterly in Spring, Summer, Fall and Winter by the Association for the Advancement of Baltic Studies, Inc (AABS). The AABS is an international educational and scholarly non-profit organization for the promotion of research and education in Baltic Studies on an international level.

\section{RECENT ARTICLES:}

Overcoming the Past: Polish-Lithuanian Relations, 1990-1995

- Stephen R Burant, US Department of State

Dogma, Art, and Politics: Roman Aspects of St. Casimir's Chapel in Vilnius

- K Paul Zygas, Arizona State University

Minority Nationalism and the Politics of Gender: Baltic German Women in the Late Imperial Era

- Anders Henriksson, Shepherd College

Editor: Dr. Saulius Sužiedèlis

History Department

Millersville University

P. 0. Box 1002

Millersville, PA 17551-0302

Tel (717) $872-3581$ Fax: (717) $871-2485$

E-Mail. ssuziede@marauder.millersv.edu

Subscriptions. $\$ 60.00$ per year. Back copies available, No agency discount Individual readers are invited to join the AABS as members at $\$ 50.00$ per year, full-time students $\$ 2500$, seniors $\$ 3000$ Memberships include subscriptions to the $J B S$ and its sister publication, the quarterly Baltic Studies Newsletter All prices quoted in US currency, and include air delivery to overseas addresses, For subscriptions, membership information, or a free sample copy, contact:

\section{AABS Executive Office}

111 Knob Hill Road

Hackettstown, NJ $07840-4222$ U. S. A

Tel: (908) 852-5258 Fax: (908) 852-3233

E-Mail.70762.640@compuserve.com

(Advertising rate card available on request from same address) 
NATIONALITIES PAPERS is the only journal in the world which deals exclusively with all nationalities of the former USSR, and also with national minorities in Eastern and Central European countries. The problems and importance of over 140 million people are treated with the disciplinary and methodological contexts of PostSoviet and Europe-Asia studies. Of central concern is the fate of the Balts, Ukrainians, Jews and the peoples of Central Asia and the Caucasus. Nationalities Papers is an international and multidisciplinary journal with contributors and readers throughout North America, Western and Eastern Europe, the Far East, Japan and the People's Republic of China. Included in each general issue are in-depth analyses from the historical view, updates on latest developments, some original documents, and book reviews; some issues concentrate on a region or nationality as a special topic, which exclusive focus allows for more extensive and detailed information.

Submission of manuscripts. For information on submitting manuscripts, write to: Professor Henry R. Huttenbach, Editor-in-Chief, Nationalities Papers, Department of History, The City College of New York, 138th Street and Convent Avenue, New York, NY 10031, USA.

Business correspondence, including orders and remittances related to subscriptions, back issues, offprints and advertisements, should be addressed to the publisher: Carfax Publishing Company, PO Box 25, Abingdon, Oxfordshire OX14 3UE, UK.

THE ASSOCIATION FOR THE STUDY OF NATIONALITIES

Stanford University, Stanford, CA 94305-6010

Phone: (415) 723-0768

Fax: (415) 723-1687

E-mail: asn@hoover.stanford.edu

President Ian Bremmer, Institute for EastWest Studies

Vice-Presidents Mark Beissinger, University of Wisconsin

Frank Golczewski, Hamburg University

Alex Motyl, Columbia University

Treasurer

Steven Sabol, Georgia State University

Secretary

Dominique Arel, Columbia University 


\section{RECENT SPECIAL ISSUES}

The Soviet Nationalities Against Gorbachev (Spring, 1990)

Social Movements in the USSR (Fall, 1990)

The Soviet Nationalities Despite Gorbachev (Spring, 1991)

Pamyat (Fall, 1991)

The Gypsies in Eastern Europe (Fall, 1991)

Religious Consciousness in the Glasnost Era (Spring, 1992)

The Ex-Soviet Nationalities Without Gorbachev (Fall, 1992)

Voices from the Slovene Nation, 1990-1992 (Spring, 1993)

Ethnopolitics in Poland: Jews and Communism

1918-1968 (Summer, 1994)

Visions and Policies: Estonia's Path to Independence and Beyond, 1987-1993 (Spring, 1995)

\section{FORTHCOMING SPECIAL ISSUES}

The Emergence of Moldova

The Disintegration of Yugoslavia

A Focus on the New Ukraine

Muslims in the Balkans

Eurasian Border Issues Old and New

The Volga Germans

International

Periodical 